\title{
The Impact of Access to Electricity on E-Commerce Adoption in Ghanaian SMEs, an Empirical Analysis
}

\author{
Christiana Twi-Brempong ${ }^{*}$, Hejun Gu${ }^{1}$, Tetelesti Oppong-Baah ${ }^{1}$, Isaac Owusu ${ }^{1}$, \\ Edward Gyamfí2 , Jovanka Pinas' ${ }^{1}$, Elina Kim¹, Adjoa Afedua Nsaful1, Frederick Adjei Boateng1, \\ Deborah Ofosu' ${ }^{1}$, Emmanuel Nketiah', Mavis Adjei', Samuel Koranteng Fianko ${ }^{3,4}$, \\ Kweku Kyei Gyamerah'5 Joyce A. Owusu ${ }^{6}$
}

\author{
${ }^{1}$ School of Business, Nanjing University of Information Science \& Technology, Nanjing, China \\ ${ }^{2}$ College of Economics and Management, Nanjing Agricultural University, Nanjing, China \\ ${ }^{3}$ Central University of Technology, Bloemfontein, South Africa \\ ${ }^{4}$ Marshalls University College, Accra, Ghana \\ ${ }^{5}$ Unibank Ghana Limited, Accra, Ghana \\ ${ }^{6}$ College of Economics and Management, Nanjing Tech University, Nanjing, China \\ Email: ^brempong7@icloud.com, ^t.oppongbaah@gmail.com
}

How to cite this paper: Twi-Brempong, C., Gu, H.J., Oppong-Baah, T., Owusu, I., Gyamfi, E., Pinas, J., Kim, E., Nsaful, A.A., Boateng, F.A., Ofosu, D., Nketiah, E., Adjei, M., Fianko, S.K., Gyamerah, K.K. and Owusu, J.A. (2020) Paper Title. Open Journal of Business and Management, 8, 245-261. https://doi.org/10.4236/ojbm.2020.81015

Received: November 23, 2019

Accepted: December 27, 2019

Published: December 30, 2019

Copyright $\odot 2020$ by author(s) and Scientific Research Publishing Inc. This work is licensed under the Creative Commons Attribution International License (CC BY 4.0).

http://creativecommons.org/licenses/by/4.0/

\begin{abstract}
This paper explores the impact of selected factors that affect the adoption of E-commerce among small and medium-sized enterprises (SMEs) in Ghana, with emphasis on access to electricity. The data included figures for the country's population growth (PG), secondary education (SEC), individuals using the internet (IUI), broadband subscriptions both fixed and mobile (BBS), access to electricity (AE) and secure internet servers (SIS). The data was from the year 2007 up to 2017. The main objective is to identify the various factors that impact e-commerce adoption in Ghana. This study uses regression to conduct an empirical analysis on the impact these factors have on e-commerce in Ghana. The study found that access to electricity had a strong positive relationship with e-commerce adoption in the country. This can explain why e-commerce has not been broadly adopted and used in Ghana since the country has been experiencing a huge power crisis for the past decade. Broadband subscription and secure internet servers also impacted e-commerce adoption at various percentages but access to electricity was statistically significant. Based on the findings, the author suggests that the government, policymakers and other stakeholders make great efforts to solve the power crises in the country as doing such will give businesses an incentive to conduct business online.
\end{abstract}


Keywords

E-Commerce, Small and Medium-Sized Enterprises (SMEs)

\section{Introduction}

\subsection{Definition of SMEs}

The definition for SMEs varies depending on the country. Some definitions are based on the total revenue of the business and others on the number of employees. The EU defines a medium-sized enterprise as one with a staff headcount less than 250, turnover less than or equal to fifty million $(50 \mathrm{~m})$ Euros and a balance sheet total less than or equal to forty-three million $(43 \mathrm{~m})$ Euros. The union also defines a small enterprise as one with a less than fifty (50) staff headcount, less than or equal to ten million $(10 \mathrm{~m})$ Euros and a balance sheet total less than or equal to ten million $(10 \mathrm{~m})$ Euros. It also defined a micro enterprise as one with less than ten (10) employees and turnover or balance sheet total less than or equal to two million Euros.

The National Board for Small Scale Industries (NBSSI) which regulates SMEs in Ghana defines SMEs as enterprises with turnover greater than two hundred thousand US dollars (US $\$ 200,000$ ) but less than five million dollars (US $\$ 5 \mathrm{~m}$ ) equivalent. The Ghana Statistical Service however defines SMEs as enterprises that employ 1 to 5 people as micro, 6 to 30 people as small, and 31 to 100 people as medium sized enterprises. This paper adopts the definition offered by the Ghana Statistical Service.

\subsection{Definition of E-Commerce}

E-commerce is similar to the traditional way of marketing, except entirely electronic. Zwass [1] defined e-commerce as the sharing of business information, maintaining business relationships and conducting business transactions by means of telecommunications networks.

\subsection{Overview of SMEs in Ghana}

According to the most current Integrated Business Establishment Survey (IBES II) conducted by the Ghana Statistical Service (GSS), SMEs employed $71.4 \%$ of Ghana's total workforce while large companies employed only $16.6 \%$ of the workforce. Out of 3,102,917 people surveyed, only 515,152 people worked in large enterprises and the remaining 2,587,765 people worked in SMEs.

Ghana as an emerging economy relies heavily on SMEs' contribution to the economy. SMEs in the country produce a larger volume of goods than larger enterprises do. The sector employs a lot more people than the larger corporations and hence produces a lot more. They contribute to $75 \%$ of the country's GDP (IBES II). As SMEs make up most of the businesses in the country, they provide the government of Ghana with tax for its operations. Compared with any other 
form of businesses in the country, SMEs are the major tax sources for the government.

\subsection{Problems Faced by Ghanaian SMEs}

Firstly, there is little or no credit access for SMEs in Ghana. Only 59\% of small firms and $35 \%$ of medium-sized firms had access to finance according to the 2013 Ghana Enterprise Survey. The International Labor Organization (ILO) cited unfavorable interest rates as a reason why most SMEs in Ghana do not apply for loans. Also, the practice of not keeping proper accounts makes it hard for financial institutions to assess the credit worthiness of SMEs in the country.

Inefficient management is another major problem SMEs in Ghana. This is mostly due to the fact that a lot of these enterprises are family owned and the heads of the families are naturally the managers. Some of these people have little to no managerial skills and abilities and are appointed to these positions solely on the basis of nepotism. Aryeetey et al. [2] found that higher proportions of SME owners and operators in the nation had low levels of literacy and numeracy to understand, accept and apply new ways of doing business thus impacting negatively on their operations.

Other problems include the inability to capitalize on advanced technology due to lack of awareness, knowledge or cost, regulatory and legal constraints, lack of formal training in business lines, information asymmetry rising from lack of accounting records and other financial documents.

\subsection{Purpose and Significance of Research}

The adoption of e-commerce offers SMEs a great opportunity to expand their access on a global scale. Its application in the SME sector would benefit enterprises in the way they communicate, and how they achieve their marketing objectives, thus improving efficiency of operations. However, Statistical data from the Registrar General's Department indicated that an enormous $92 \%$ of all registered companies in the country are SMEs. Villars [3] and Hayford [4] stated that, SMEs add 70\% to the country's Gross Domestic Product (GDP) and account for $92 \%$ of businesses in the private sector of Ghana.

The introduction of e-commerce into the mainstream operations of SMEs can offer unique opportunities to overcome specific challenges. It is upon the availability of electricity and internet that e-commerce can efficiently be adopted and used. However, e-commerce adoption among Ghanaian SMEs is subpar, thus the fundamental problem motivating this study is the need to understand the impact of access to electricity on the adoption of e-commerce in Ghana and also to identify the various factors impact e-commerce adoption in Ghana.

The results expected from this research will be beneficial to the government, managers and owners of SMEs as it will help them to address the factors preventing the adoption of e-commerce and prompt them with the benefits that can be derived from its adoption and use. Policy makers can also consider the results and incorporate the recommendations when coming up with policies to 
regulate the sector since the country stands to gain a lot from the adoption of e-commerce by SMEs.

\section{Literature Review}

\subsection{An Overview of ICT Adoption among SMEs}

Many opportunities lie in the adoption and integration of ICT into the operations of SMEs. The integration of ICT allows small businesses to compete efficiently and successfully locally and internationally. The internet and ICT in general have provided immense benefits to small businesses, as ICT continues to evolve, it has provided numerous research opportunities [5].

Studies have revealed that large organizations generally have the resources to adopt ICTs whereas the SMEs that are desirous to adopt are handicapped by financial and human resources. Although ICTs are much cheaper than before, they still represent a considerable investment for SMEs that usually lack such funds. Besides, SMEs usually do not have the appropriate skills available in-house and thus have to train existing staff or outsource most ICT functions of the organization [6].

The major challenges of ICT adoption by SMEs in Ghana include high implementation costs, poor or inadequate telecommunication infrastructure, lack of in-house technical expertise, high level of complexity, incompatibility between existing infrastructure and ICTs, frequent power interruption (according to the 2013 Ghana Enterprise Survey, SMEs had 8.5 number of power outages in a typical month) and small scale operation.

Despite these challenges, the firms surveyed cited these as drivers for the adoption of ICT in their operations: improve customer service, competitive advantage, improve internal and external communication, increase profits, current trend, improve production planning and improve quality control among many others [6].

\subsection{Theoretical Foundations in E-Commerce Adoption Research}

This section reviews the most commonly used theories that have been employed in technology adoption, especially e-commerce adoption research in small and medium-sized enterprises. In review are the following: The Theory of Planned Behavior (TPB), the Technology Acceptance Model (TAM), the Technology-Organization-Environment (TOE) framework, the Perceived E-readiness Model (PERM), the Diffusion of Innovation Theory (DIT), and the Resource Based Theory (RBT) combined with Contextualism.

\subsubsection{The Hierarchical Phases of E-Commerce Adoption (PERM Model)}

The Perceived E-Readiness Model was proposed to fit the context of developing countries. The model considers some internal organizational factors, known as perceived organizational e-Readiness (POER), and external factors, identified as perceived external e-Readiness (PEER), as important for e-commerce adoption. According to the authors, POER comprises of the organization's perception, 
comprehension, and projection of e-commerce and its potential benefits and risks (innovation imperative attributes), the commitment of its managers (managerial imperative attribute); and key organizational components, such as its resources, processes, and business infrastructure (organizational imperative attributes). They identified the PEER factors to include an organization's assessment and evaluation of relevant external environmental factors (environmental imperative attributes) such as Government e-Readiness, Market Forces e-Readiness and Support Industries e-Readiness [7]. The authors further claim that PERM can assist organizations in developing countries to locate, measure and manage risks in e-commerce adoption activities.

According to Molla and Licker [7], in their Perceived E-Readiness Model (PERM Model), e-commerce adoption can be presented in hierarchical phases and these phases are: no e-commerce, connected e-commerce, static e-commerce, interactive e-commerce, transactive e-commerce, and integrated e-commerce.

\subsubsection{Diffusion of Innovation Theory (DIT)}

The Diffusion of Innovation Theory (DIT) was proposed by Everett Rogers in his 1995 book titled Diffusion of Innovations. The Diffusion of Innovation Theory observes that individuals possess different degrees of willingness to adopt innovations and thus it is generally observed that the portion of the population adopting an innovation is approximately normally distributed over time along an S-shaped curve [8]. This led to the classification of adopters into five categories:

1) Innovators: These are people who want to be the first to try the innovation. They are venturesome and interested in new ideas. These people are very willing to take risks, and are often the first to develop new ideas. Very little, if anything, needs to be done to appeal to this population.

2) Early Adopters: These are people who represent opinion leaders. They enjoy leadership roles, and embrace change opportunities. They are already aware of the need to change and so are very comfortable adopting new ideas. Strategies to appeal to this population include how-to manuals and information sheets on implementation. They do not need information to convince them to change.

3) Early Majority: These people are rarely leaders, but they do adopt new ideas before the average person. That said, they typically need to see evidence that the innovation works before they are willing to adopt it. Strategies to appeal to this population include success stories and evidence of the innovation's effectiveness.

4) Late Majority: These people are skeptical of change, and will only adopt an innovation after it has been tried by the majority. Strategies to appeal to this population include information on how many other people have tried the innovation and have adopted it successfully.

5) Laggards: These people are bound by tradition and very conservative. They are very skeptical of change and are the hardest group to bring on board. Strategies to appeal to this population include statistics, fear appeals, and pressure 
from people in the other adopter groups.

Although the Diffusion of Innovation Theory has been popular and replicated in several studies [9] [10] [11], it has faced several criticisms, especially those that question its applicability in complex and network based environments [12].

\subsection{Classification of E-Commerce}

E-commerce can be classified into the following groups according to [13]. Business-to-Business (B2B): When business entities or organizations participate with other businesses or organizations to do e-commerce (known as B2B). This just involves business to business interactions, whether it is purchasing, sales or just the exchange of information conducted electronically.

Business-to-Consumers (B2C): When a business or organization entity provides products or services to individual customers (known as B2C). Turban et al., [13] also calls it e-tailing because it includes retail transactions of shoppers. This is basically the electronic form of traditional brick and mortar retailing. It is also the most common form of e-commerce.

Consumer-to-Business (C2B): Is a type of e-commerce in which individuals use the Internet to sell products or services to organizations, as well as, individuals who seek sellers to bid on products or services they need. As the name implies, it involves sole individuals selling various products to business organizations.

Mobile Commerce (M-commerce): this encompasses e-commerce transactions and activities conducted in full or in part in a wireless environment. Further, $\mathrm{m}$-commerce transactions targeted to individuals in specific locations, at specific times are known as location-based commerce (or l-commerce).

Intrabusiness e-commerce: this includes all internal organizational activities that involve the exchange of goods, services, or information among various units and individuals in that organization. All business activities conducted or exchanges between the different departments and sections of an organization can be classified under this form of e-commerce. It promotes efficiency and effectiveness in the business processes within an organization.

Business-to-Employees (B2E): An e-commerce model in which an organization delivers services, information or products to its individual employees. It involves all electronically conveyed messages, instructions, queries and feedback along an organization's structure (Table 1).

\subsection{Empirical Literature}

\section{See Table 2.}

\section{Research Methodology}

\subsection{Data Source}

The basis of analysis was based on the use of secondary data collected from the world bank from the year 2007 up until 2017. Data from the Ghana Enterprise 
Table 1. Major E-commerce platforms in Ghana.

\begin{tabular}{|c|c|c|}
\hline Name & Year of inception/Website & \\
\hline eShopAfrica.com & $\begin{array}{l}\text { online since } 2001 \\
\text { and eShopAfrica.com }\end{array}$ & $\begin{array}{l}\text { The company is registered in Ghana as an } \\
\text { export only company promoting products } \\
\text { from the non-traditional sector. }\end{array}$ \\
\hline Tonaton & Tonaton.com & $\begin{array}{l}\text { Tonaton.com has the widest selection } \\
\text { of popular second hand items all over } \\
\text { Ghana, which makes it easy to find } \\
\text { exactly what you are looking for }\end{array}$ \\
\hline Carmudi & carmudi.com.gh & $\begin{array}{l}\text { According to the website, "Our role is to } \\
\text { help you find the right car and make the } \\
\text { link with the owner. As a member of the } \\
\text { family Rocket Internet, we bring our } \\
\text { unrivaled experience in the launch of } \\
\text { hundreds of companies around the world. }\end{array}$ \\
\hline $\begin{array}{c}\text { Heel The } \\
\text { World (HTW) }\end{array}$ & 2012 and htwshoes.com & $\begin{array}{l}\text { According to HTW: "We make high-end } \\
\text { bespoke men's shoes and leather } \\
\text { accessories and use some of the proceeds } \\
\text { to support people in the start-up space, } \\
\text { collaborate with younger fashion brands, } \\
\text { and have paid internships annually." }\end{array}$ \\
\hline Lamudi & lamudi.com.gh & $\begin{array}{l}\text { Lamudi helps people find their ideal home, } \\
\text { land and commercial property. }\end{array}$ \\
\hline Jumia & jumia.com.gh & $\begin{array}{l}\text { According to the company, it offers } \\
\text { consumers a wide selection of styles and } \\
\text { brands, } 100 \% \text { convenience with our } 24 / 7 \\
\text { online access from your home or office, } \\
\text { secure payment such as Bank Deposit/Online } \\
\text { banking and Cash on Delivery, exceptional } \\
\text { customer care service, fast next-day delivery } \\
\text { and returns after } 7 \text { days }\end{array}$ \\
\hline OLX & olx.com.gh & $\begin{array}{l}\text { OLX, another classifieds platform focused } \\
\text { on emerging markets, both mobile and } \\
\text { online. OLX is the next generation } \\
\text { of free online classifieds }\end{array}$ \\
\hline Baahe.com & baahe.com & $\begin{array}{l}\text { Baahe.com is the subsidiary store to Kaizen } \\
\text { Global Consult which specializes in the sales } \\
\text { of high quality and affordable electronic } \\
\text { devices as well as sales consultancy }\end{array}$ \\
\hline Tisu & tisu.com.gh & $\begin{array}{l}\text { Tisu is a local daily deals and discounts } \\
\text { website for the very best that Accra has to } \\
\text { offer. The website claims to give consumers } \\
\text { an easy \& fun way to get huge discounts while } \\
\text { discovering new places all across the city. }\end{array}$ \\
\hline Zoobashop & Zoobashop.com & $\begin{array}{l}\text { Zoobashop.com is a Ghanaian-owned } \\
\text { online retail store that offers a variety of } \\
\text { electronics, home appliances, items of } \\
\text { fashion etc., at decent prices. Zoobashop } \\
\text { allows several modes of payment, from } \\
\text { the conventional cash-on-delivery to } \\
\text { online credit/debit card payments }\end{array}$ \\
\hline Souq Afrique & tore.souqafrique.com & $\begin{array}{l}\text { Souq Afrique is a company that celebrates } \\
\text { African creativity. The website stocks } \\
\text { products that are made in Africa } \\
\text { or inspired by Africa. }\end{array}$ \\
\hline
\end{tabular}


Table 2. Summary of other literature on e-commerce adoption in Ghana.

\begin{tabular}{|c|c|c|c|c|}
\hline Author (s) & Title of Research Paper & Objective (s) & Research Method & Results or Findings \\
\hline GYAMFI [14] & $\begin{array}{l}\text { Factors affecting the } \\
\text { adoption of } \\
\text { e-marketing } \\
\text { among SMEs; } \\
\text { Case study of selected } \\
\text { SMEs in the } \\
\text { Kumasi metropolis, } \\
\text { Ashanti region. }\end{array}$ & $\begin{array}{l}\text { To identify the various } \\
\text { factors affecting the } \\
\text { decision by SMEs owners } \\
\text { and managers to adopt } \\
\text { the technology or not. In } \\
\text { addition, to ascertain the } \\
\text { level to which each factor } \\
\text { influences their decisions } \\
\text { to adopt the technology. }\end{array}$ & $\begin{array}{l}\text { Quantitative approach } \\
\text { was used to determine } \\
\text { the magnitude of each } \\
\text { factor in influencing } \\
\text { adoption of } \\
\text { E-Marketing among } \\
\text { SMEs. A qualitative } \\
\text { approach was useful to } \\
\text { provide the researcher } \\
\text { with perspective. }\end{array}$ & $\begin{array}{l}\text { The main factors inhibiting } \\
\text { the adoption of electronic } \\
\text { marketing among SMEs in } \\
\text { Kumasi are: technological } \\
\text { incompatibility with target } \\
\text { markets; lack of knowledge; } \\
\text { stakeholder's unreadiness; } \\
\text { technology disorientation } \\
\text { as well as perception. }\end{array}$ \\
\hline $\begin{array}{l}\text { Boateng, R. Molla, } \\
\text { A., Heeks, R. and } \\
\text { Hinson, R. [15]. }\end{array}$ & $\begin{array}{l}\text { Advancing E-commerce } \\
\text { Beyond Readiness in a } \\
\text { Developing Country: } \\
\text { Experiences of Ghanaian } \\
\text { Firms }\end{array}$ & $\begin{array}{l}\text { To identify factors } \\
\text { affecting the assimilation } \\
\text { of electronic commerce } \\
\text { in Ghana and the } \\
\text { solutions that Ghanaian } \\
\text { firms have developed. }\end{array}$ & $\begin{array}{l}\text { CPT Framework } \\
\text { (Bajaj \& Leonard, } \\
\text { 2004) and PERM } \\
\text { Model } \\
\text { (Molla \& Licker, [7] }\end{array}$ & $\begin{array}{l}\text { social networks, managerial } \\
\text { capabilities and government } \\
\text { commitment has an attendant } \\
\text { effect on adoption and } \\
\text { use of tangible resources like } \\
\text { electronic commerce applications. }\end{array}$ \\
\hline $\begin{array}{c}\text { GARIBA } \\
\text { FUSEINI [16] }\end{array}$ & $\begin{array}{l}\text { Small And } \\
\text { Medium-Sized } \\
\text { Enterprises' (Smes') } \\
\text { Access To Credit In } \\
\text { Ghana: Determinants } \\
\text { And Challenges }\end{array}$ & $\begin{array}{l}\text { To find the factors } \\
\text { that influence SMEs' } \\
\text { demand for and access } \\
\text { to credit in Ghana. }\end{array}$ & $\begin{array}{l}\text { Firm-level survey } \\
\text { of } 720 \text { firms which } \\
\text { was conducted by the } \\
\text { World Bank in } \\
\text { Ghana in } 2013 \text {. }\end{array}$ & $\begin{array}{l}\text { All Ghanaian firms in general, and SMEs } \\
\text { in particular, face credit constraints. } \\
\text { Complex application process; } \\
\text { unfavorable interest rates, } \\
\text { high collateral requirement and short } \\
\text { loan maturity period were major } \\
\text { obstacles preventing them from } \\
\text { applying for credit. }\end{array}$ \\
\hline $\begin{array}{l}\text { Taylor and } \\
\text { Owusu [17] }\end{array}$ & $\begin{array}{l}\text { Factors Affecting } \\
\text { Internet and } \\
\text { e-Commerce Adoption } \\
\text { among Small and } \\
\text { Medium-Sized Enterprise } \\
\text { Non-Traditional } \\
\text { Exporters: Case } \\
\text { Studies of Ghanaian } \\
\text { Handicraft Exporters }\end{array}$ & $\begin{array}{l}\text { To examine the } \\
\text { factors that affect } \\
\text { Internet and } \\
\text { E-commerce } \\
\text { adoption among small } \\
\text { exporting handicraft } \\
\text { firms in Ghana. }\end{array}$ & $\begin{array}{l}\text { Using interviewing, } \\
\text { the study presented } \\
\text { an in-depth analysis } \\
\text { of the cases of two } \\
\text { major Ghanaian } \\
\text { Handicraft } \\
\text { Exporters that have } \\
\text { been using the } \\
\text { internet in their } \\
\text { business operations. }\end{array}$ & $\begin{array}{l}\text { The internal factors that: } \\
\text { Affected internet and e-commerce } \\
\text { adoption of the firms were } \\
\text { perceived benefits of the technology } \\
\text { from owner/manager } \\
\text { Characteristics, lack of qualified } \\
\text { staff to develop and support } \\
\text { e-commerce website from firm } \\
\text { characteristics, and limited } \\
\text { Resources from cost and return on } \\
\text { investment. The key external factors } \\
\text { affecting the adoption included } \\
\text { limited Internet } \\
\text { Service Providers (ISP), lack of online } \\
\text { payment process, pricing structures, and } \\
\text { limited availability of online banking } \\
\text { Services, power failure, and low } \\
\text { competition in the industry. }\end{array}$ \\
\hline $\begin{array}{c}\text { Seth Kwaku } \\
\text { Amoah and Alfred } \\
\text { Kwabena Amoah [18] }\end{array}$ & $\begin{array}{l}\text { The Role of Small and } \\
\text { Medium Enterprises } \\
\text { (SMEs) to } \\
\text { Employment in Ghana }\end{array}$ & $\begin{array}{l}\text { To assess the role that } \\
\text { MSMEs (Micro, Small } \\
\text { and Medium-Sized } \\
\text { Enterprises) are playing } \\
\text { with respect to } \\
\text { employment in Ghana }\end{array}$ & descriptive statistics & $\begin{array}{l}\text { MSMEs in Ghana offered } \\
\text { employment of about } 82 \text { percent to } \\
\text { the working population in the } \\
\text { country with marked differences in } \\
\text { the different regions in the country. }\end{array}$ \\
\hline $\begin{array}{c}\text { Mohammed } \\
\text { Abdulai Mahmoud } \\
{[19]}\end{array}$ & $\begin{array}{l}\text { Market Orientation and } \\
\text { Business Performance } \\
\text { among SMEs in Ghana }\end{array}$ & $\begin{array}{l}\text { To investigate the market } \\
\text { orientation-performance } \\
\text { link among } \\
\text { Ghanaian SMEs }\end{array}$ & survey & $\begin{array}{l}\text { The development of market } \\
\text { orientation in this sector rests more } \\
\text { on the attitude of owners/Managers. } \\
\text { Market orientation leads to superior } \\
\text { performance under ceaseless } \\
\text { competitive conditions. }\end{array}$ \\
\hline
\end{tabular}




\begin{tabular}{|c|c|c|c|c|}
\hline Sydney Hayford [4] & $\begin{array}{l}\text { The Development of } \\
\text { Small Medium } \\
\text { Enterprises and their } \\
\text { impact to the } \\
\text { Ghanaian Economy }\end{array}$ & $\begin{array}{l}\text { To find the importance } \\
\text { of the SME sector to the } \\
\text { Ghanaian economy } \\
\text { and the challenges } \\
\text { facing the sector. }\end{array}$ & $\begin{array}{l}\text { Interviews, } \\
\text { questionnaires, } \\
\text { publications } \\
\text { and reports }\end{array}$ & $\begin{array}{l}\text { The sector is a major contributor } \\
\text { to the country's GDP, } \\
\text { performing very well. } \\
\text { Some of the problems faced by } \\
\text { the sector were lack of access to } \\
\text { credit facility, inefficiencies with } \\
\text { their management, inability to capitalize } \\
\text { on advanced technology, regulatory and } \\
\text { legal constraints. }\end{array}$ \\
\hline
\end{tabular}

Survey also conducted by the World Bank but through the Ghana Statistical Service (GSS) and internet usage data was obtained from liveinternetstats.com and backed by the International Telecommunications Union (ITU).

\subsection{Data Analysis}

In this section, descriptive statistics (i.e. means, standard deviations, minimum and maximum values of variables) and diagnostic testing based on heteroscedasticity test and test for multicollinearity were implemented for the research study. A model was also estimated.

\subsubsection{Variable Description}

In this research, e-commerce is the dependent variable and since e-commerce in itself is not measurable, internet usage was used as a proxy for e-commerce. The independent variables used were population growth annual percentage (PG), individuals using the internet (IUI) as a percentage of population, secure internet servers (SIS) per 1 million people, broadband subscriptions (BBS) mobile and fixed, secondary education (SEC) as a percentage of population and access to electricity (AE).

Population growth refers to the rate at which the population of individuals in a specific location increases or decreases (negative growth). Ghana, like most of the other countries in the sub-Saharan region experiences positive growth in its population. The country has an average population growth rate of $2.4 \%$ annually.

Ghanaian individuals using the internet have grown gradually from $3.85 \%$ in 2007 to $37.88 \%$ in 2017 . The growth has been very slow and can be attributed to factors like the high cost of securing internet in the country and also the poor quality and slow speed of the available internet does not encourage its use.

Secure internet servers are servers using encryption technology in Internet transactions. As at 2017, statistics from the World Bank ranks Ghana at number 84 in the world on the basis of secure internet servers per 1million people.

Broadband subscription refers to subscriptions to high-speed access to the public Internet. The study used figures for both fixed and mobile subscriptions per 100 people. 2016 was shown to be the peak with a value of 0.30 . This value fell sharply in 2017 to 0.19 for unknown reasons. Secondary education measured the percentage of the population that had a secondary school education. This 
was considered a factor because it shows the literacy rate of the population. The value increased from $46 \%$ in 2007 to $62 \%$ in 2017.

The final variable is access to electricity. The data covered the percentage of the Ghanaian population that has access to electricity. The value was shown to be 79.3 as at 2017 .

\subsubsection{Diagnostic Statistics}

The following diagnostic testing was conducted on the datasets: test for multicollinearity and Pearson correlation were implemented.

\section{Test of Multicollinearity}

The study uses multicollinearity on regression estimates to assess the effects of different degrees of multicollinearity using variance inflation factor (VIF) [20]. The decision criteria are that if the VIF is greater than 10 then there exists multicollinearity and vice versa.

The general hypotheses:

$\mathrm{H}_{0}$ : there is no multicollinearity on regression estimates.

$\mathrm{H}_{\mathrm{a}}$ : there is multicollinearity on regression estimates.

\section{Test of Autocorrelation}

The Durbin-Watson test is simply

$$
D W=\frac{\sum_{i=2}^{n}\left(e_{i}-e_{i-1}\right)^{2}}{\sum_{i=1}^{n} e_{i}^{2}}
$$

The general hypotheses:

$\mathrm{H}_{0}$ : there is no autocorrelation in the errors.

$\mathrm{H}_{\mathrm{a}}$ : there is autocorrelation.

Decision criteria here is that if the R-squared is lower than dwatson statistics, then we cannot reject the null hypothesis that is no autocorrelation in the errors.

Pearson correlation

$$
R^{2}=\left(\frac{\sum_{i=1}^{n}\left(D_{i}-\bar{D}\right)\left(I N D_{i}-\overline{I N D}\right)}{\sqrt{\sum_{i=1}^{n}\left(D_{i}-\bar{D}\right)^{2}} \sqrt{\sum_{i=1}^{n}\left(I N D_{i}-\overline{I N D}\right)^{2}}}\right)^{2}
$$

The general hypotheses:

$\mathrm{H}_{0}$ : there is no relationship between e-commerce and the explanatory variables.

$\mathrm{H}_{\mathrm{a}}$ : there is a strong positive relationship between ecommerce and the explanatory variables Decision criteria here is that if the R-squared is more than 0.5 than there is a strong (positive) relationship between the dependent and the explanatory variables, then we reject the null hypothesis that is there is no relationship between e-commerce and the explanatory variables.

Empirical Estimation Model

The basic form of the model used is:

Consider a hypothetical data set $x_{1}, x_{2}, x_{3}, x_{n}, y$, and a hypothesized linear regression model 


$$
y_{1}=\beta_{0}+\beta_{1} x_{1 i}+\beta_{2} x_{2 i}+\cdots+\beta_{n} x_{n i}+\varepsilon_{i}
$$

\section{Results and Discussion}

\subsection{Descriptive Statistics}

Table 3 presents results of the variables used in the study. The study analysis is restricted to only the World Bank Enterprise Survey with data from 2007-2017 (i.e. 11 years). The results show that the average percentage of people with secondary school education is $56.2 \%$, with a maximum percent of 62.1 and a minimum of 46.3. Population growth had a mean value of 2.4 with a minimum value of 2.19 and a maximum of 2.62. Individuals using the internet had a mean percentage of 16.8 with a minimum percent of 3.85 and a maximum of 37.88 . Secure internet servers per a million people had an average of 25.5 with a minimum of 0.89 and a maximum of 97.88 . Broad band subscription (both mobile and fixed) had a mean of 46 with a minimum of 16.7 and a maximum of 68 . The last variable, that is access to electricity had an average mean of 69.4 with a minimum of 58.79 and a maximum of 79.3 .

\subsection{Diagnostic Statistics}

\subsubsection{Test of Multicollinearity}

To illustrate the effects of different degrees of multicollinearity on regression estimates, multicollinearity was assessed using variance inflation factor (VIF) [21]. This VIF factor measures the inflation in the variances of the parameter estimates due to multicollinearity potentially caused by the correlated predictors. This is essential when at least two highly correlated predictors are assessed simultaneously in a regression model. If the VIF is greater than 10 then there exists multicollinearity and vice versa. The results showed that the null hypothesis is rejected, which means that there is no evidence of multicollinearity.

Initially, the study used six explanatory variables, however their VIF was greater than 10 (see in appendix). The study therefore dropped, population growth, secondary education and individuals using the internet and re-run the test again. The experiment was repeated until the following explanatory variables were below 10 (Table 4). The results from Table 4 shows that AE presented VIF of 7.77, BBS had a VIF of 7.78 and SIS had a VIF of 4.07.

Table 3. Descriptive Statistics for selected dependent and explanatory variables.

\begin{tabular}{cccccc}
\hline Variable & Observations & Mean & Standard deviation & Minimum & Maximum \\
\hline SEC & 11 & 56.18576 & 5.799968 & 46.33615 & 62.10504 \\
PG & 11 & 2.412341 & 0.1493212 & 2.198185 & 2.618937 \\
IUI_P & 11 & 16.86105 & 13.00519 & 3.85 & 37.88 \\
SIS_P & 11 & 25.55383 & 36.08554 & 89.75158 & 97.88445 \\
BBS_MF & 11 & 46.03592 & 17.07991 & 16.78453 & 68.05411 \\
AE_P & 11 & 69.44877 & 7.731481 & 58.79233 & 79.3 \\
\hline
\end{tabular}


Table 4. Multicollinearity results for all variables.

\begin{tabular}{ccc}
\hline Variable & VIF & $1 /$ VIF \\
\hline LNBBS & 7.78 & 0.128598 \\
LNAE & 7.77 & 0.128699 \\
LNSIS & 4.07 & 0.245844 \\
Mean VIF & 6.54 & \\
\hline
\end{tabular}

\subsubsection{Test for Autocorrelation}

Since the R-squared is lower than the dwatson statistics, then we cannot reject the null hypothesis that is no autocorrelation in the errors (Table 5).

\subsubsection{Pearson Correlation}

Since the R-squared is more than 0.5 , there is a strong (positive) relationship between the dependent and the explanatory variables, then we reject the null hypothesis that is there is no relationship between e-commerce and the explanatory variables.

The results show that Access to electricity had the highest number hence it is the factor with the most impact on e-commerce adoption in the country. This is very reasonable considering the fact that electricity is needed to power ICT equipment like computers or even mobile phones in addition to other infrastructure needed for e-commerce like the internet. Without electricity, the process of e-commerce cannot take place. There is also a positive relationship between e-commerce and secure internet servers in the country. This is owing to the fact that e-commerce by definition, is commercial activities carried out online. A secure internet connection is needed to facilitate the exchange of information, goods and services and other processes in e-commerce. Finally, broadband subscription is also an important factor in e-commerce adoption and use as displayed in the results. Convenience is one of the most important perceived benefits of e-commerce and having a broadband subscription, whether mobile or fixed provides the opportunity to engage in e-commerce (Table 6).

\subsection{Multiple Regression}

Table 7 displays the regression coefficients for the model estimating the impact of selected factors on e-commerce adoption in Ghana using Pooled OLS. From the table, the model shows that only access to electricity (LNAE) was statistically significant at 5\% level in Pooled OLS estimation. This indicates that LNAE may be a good explanatory factor for the adoption and use of e-commerce in Ghana. This result is interesting but not surprising considering the energy situation in Ghana. One of Ghana's paramount constraints to economic growth is the unreliable and inadequate supply of electric power. Constant flow of electricity is an important source for economic growth and success in every nation and Ghana cannot be left out as it seeks to develop and better its economic growth and borders. The provision of continuous energy is one of the prime mandates of governments all over the world because it is upon 
Table 5. Test for autocorrelation.

\begin{tabular}{cccc}
\hline Source & SS & df & MS \\
\hline Model & 5.62439912 & 3 & 1.87479971 \\
Residual & 0.19568311 & 7 & 0.02795473 \\
Total & 5.82008223 & 10 & 0.582008223 \\
Adjusted R-squared & & 0.9520 & \\
R-squared & & 0.9664 & \\
Prob $>$ F & 0.0000 & \\
Root MSE & 0.1672 & \\
Number of observations & & 11 & \\
F(3, 7) & & 67.07 & \\
\hline
\end{tabular}

Table 6. Pearson correlation among explanatory variables used in the regression analysis.

\begin{tabular}{ccccc}
\hline Variables & LNecom & LNAE & LNSIS & LNBBS \\
\hline LNecom & 1 & & & \\
LNAE & 0.9748 & 1 & & \\
LNSIS & 0.7936 & 0.8520 & 1 & 1 \\
LNBBS & 0.9315 & 0.9256 & 0.8522 &
\end{tabular}

Table 7. Pooled Ordinary Least Squares (OLS).

\begin{tabular}{|c|c|c|c|c|}
\hline Source & SS & df & \multicolumn{2}{|c|}{ MS } \\
\hline Model & 5.62439912 & 3 & \multicolumn{2}{|c|}{1.87479971} \\
\hline Residual & 0.19568311 & 7 & \multicolumn{2}{|c|}{0.02795473} \\
\hline Total & 5.82008223 & 10 & \multicolumn{2}{|c|}{0.582008223} \\
\hline LNecom & Coefficient & Robust Standard Error & t-stastistic & $\mathrm{P}>/ \mathrm{t} /$ \\
\hline LNAE & 5.993213 & 1.321915 & 4.53 & 0.003 \\
\hline LNSIS & -0.098146 & 0.0675449 & -1.45 & 0.190 \\
\hline LNBBS & 0.5046146 & 0.331828 & 1.52 & 0.172 \\
\hline _cons & -24.62685 & 4.701356 & -5.24 & 0.001 \\
\hline Adjusted R-squared & & 0.9520 & & \\
\hline R-squared & & 0.9664 & & \\
\hline Prob $>$ F & & 0.0000 & & \\
\hline Root MSE & & 0.1672 & & \\
\hline Number of observations & & 11 & & \\
\hline $\mathrm{F}(3,7)$ & & 67.07 & & \\
\hline
\end{tabular}

*Significance level at $95 \%$.

its availability that the other resources can efficiently be extracted, hence its impact on e-commerce adoption and use. However, secure internet connection and 
broadband subscription had $\mathrm{p}$ values of more than 0.05 rendering them statistically insignificant (0.190 and 0.172 respectively). The coefficient on LNSIS is negative and this indicates that keeping all variables constant, secure internet servers predict e-commerce adoption rate by $9.8 \%$. The negative sign means that an increase in LNSIS will decrease LNecom and vice-versa. Also, the coefficient of LNBBS is 0.5046146 , indicating that by keeping all variables constant, broadband subscription predicts e-commerce adoption by $50.46 \%$. The positive indicates that an increase in broadband subscription will increase e-commerce adoption by that margin.

The model for the Pooled OLS is shown below:

$$
\begin{aligned}
\log (\text { ecom })= & -24.627+5.993 \log (\mathrm{AE})_{i t}-0.098 \log (\mathrm{SIS})_{i t} \\
& +0.505 \log (\mathrm{BBS})_{i t}+\varepsilon_{i t}
\end{aligned}
$$

\section{Conclusion and Recommendation}

\subsection{Conclusions}

The study examined secondary data from the World Bank on some factors that influence e-commerce adoption and use in Ghanaian SMEs. The data included figures for the country's population growth (PG), secondary education (SEC), individuals using the internet (IUI), broadband subscriptions both fixed and mobile (BBS), access to electricity (AE) and secure internet servers (SIS). The data was from the year 2007 up to 2017. The first three factors were dropped due to evidence of multicollinearity and the data analysis continued with the remaining factors. Broadband subscription was found to predict e-commerce adoption and use by $50.4 \%$.

Secure internet servers on the other hand explained e-commerce adoption and use only by $9.8 \%$. Its coefficient was also negative which showed a negative relationship between it and e-commerce adoption and use. Access to electricity was shown to have the strongest positive relationship with e-commerce adoption. The more people have access to internet, the more they are likely to engage in online commercial service. However, none of these is possible without electricity. This explains why e-commerce adoption in Ghana is still lagging even though the internet was first introduced to the country in 1994. In the 2013 Ghana Enterprise Survey, electricity was the second most cited obstacle for all businesses in the country, only preceded by access to credit. The Enterprise Surveys are conducted by the World Bank and its partners across all geographic regions and cover small, medium-sized and large companies. The surveys collect a range of qualitative and quantitative information through face to face interviews with firm managers and owners regarding the business environment in the country and their firm's productivity. Even large firms in the survey cited access to electricity as their third biggest obstacle. The number of power outages in a typical month was 7.9 for micro and small firms and 8 for medium-sized enterprises. Micro and small firms experienced a 44.9-day delay in obtaining an electrical connection while medium-sized enterprises experienced a 54.2-day delay. Even 
with secure internet servers and broadband subscriptions, these firms cannot engage in e-commerce because there is not enough electricity to make the use of e-commerce effective and efficient. From the survey, small and medium-sized enterprises reported $11.3 \%$ of sales loss as a result of power outages.

The findings of this study are consistent with several others on the factors affecting e-commerce adoption in Ghana. Taylor et al. [32] in their quest to find out the factors that affect small and medium-sized exporting handicraft firms in Ghana in e-commerce adoption found that factors under technological infrastructure seriously affect the enterprises' ability to adopt the Internet and e-commerce for their exporting businesses. The surveyed companies stated that they would like to use the e-commerce for their exporting activities but due to the high cost and the scarce nature of some of the telecommunications infrastructure, they were hesitant.

Boateng et al. [21] in their study titled Advancing E-commerce Beyond Readiness in a Developing Country: Experiences of Ghanaian Firms found that government-led efforts had an attendant effect on e-commerce adoption and diffusion in the country. Electricity generation and distribution in Ghana is solely owned by the government. Improvement in efforts to make electricity accessible to the whole population at reasonable cost will speed up the process of e-commerce adoption and use in the country.

\subsection{Recommendation}

The following recommendations are made as a result of the findings of the study. First of all, the severe electricity supply problem in the country has to be addressed. The electricity supply challenges in Ghana has been attributed to a number of factors, including a high level of losses in the distribution system, which is mainly due to the obsolete nature of distribution equipment, as well as nonpayment of revenue by consumers, overdependence on thermal and hydro sources for electricity generation and a poor tariff structure, which makes it difficult for the utility companies to recover the cost of electricity production. Solving Ghana's electricity challenges would require measures including, but not limited to, diversifying the electricity generation mix through the development of other hydro power and renewable energy sources for which the country has huge potential, expanding the prepaid metering system to include all public and private institutions, restructuring the tariff regime to ensure utilities can recover their cost of generation, and promoting energy efficiency programs. The government and policy makers should work together to address these challenges since universal access to electricity in the country will complement their efforts to increase internet access in the country.

Secondly, cyber laws should be enacted and enforced to ensure security of online transactions in the country. Availability of secure internet services will encourage the general population to engage in online commercial services without inhibition. 


\section{Conflicts of Interest}

The authors declare no conflicts of interest regarding the publication of this paper.

\section{References}

[1] Zwass, V. (1996) Electronic Commerce: Structure and Issues. International Journal of Electronic Commerce, 1, 3-23. https://doi.org/10.1080/10864415.1996.11518273

[2] Aryeetey, E., Baah-Nuakoh, A. and Dugglebyetal, T. (1994) Supply and Demand for Finance of Small Enterprises in Ghana. The World Bank, Washington DC. https://doi.org/10.1596/0-8213-2964-2

[3] Villars, J. (2004) Speech Delivered at a Workshop of the Ghana Investment Advisory Council. Akosombo, 5 June, 2004.

[4] Hayford, S. (2012) The Development of Small Medium Enterprises and Their Impact to the Ghanaian Economy. Unpublished Thesis, Kwame Nkrumah University of Science and Technology, Zambia.

[5] Fatima, A. and Norizon, M.Y. (2012) Model for Electronic Commerce Adoption for Small and Medium-Sized Enterprises. International Journal of Innovation, Management and Technology, 3, 90-94.

[6] Agboh (2015) Drivers and Challenges of ICT Adoption by SMES in Accra Metropolis, Ghana.

[7] Molla, A. and Licker, P.S. (2005) Perceived E-Readiness Factors in E-Commerce Adoption: An Empirical Investigation in a Developing Country. International Journal of Electronic Commerce, 10, 83-110. https://doi.org/10.1080/10864415.2005.11043963

[8] Rogers (1995) Diffusion of Innovations. 5th Edition, Free Press, New York.

[9] Hultman (2007) Rethinking Adoption: Information and Communications Technology Interaction Processes within the Swedish Automobile Industry. Jokoping International Business School, Jokoping University, Jönköping.

[10] Looi (2005) E-Commerce Adoption in Brunei Darussalam: Quantitative Analysis of Factors Influencing Its Adoption. Communications of the Association for Information Systems, 15, 61-81. https://doi.org/10.17705/1CAIS.01503

[11] IaCovou, et al. (1995) Electronic Data Interchange and Small Organisations: Adoption and Impact of Technology. MIS Quarterly, 19, 465-485.

https://doi.org/10.2307/249629

[12] Lyytinen, K. and Damsgaard, J. (2001) What's Wrong with the Diffusion of Innovation Theory: The Case of a Complex and Networked Technology? Proceedings of the International Federation for Information Processing (IFIP), Banff, Alberta, Vol. 3, 40-44.

[13] Turban, et al. (2004) Electronic Commerce: A Managerial Perspective. Pearson Prentice Hall, Upper Saddle River.

[14] Gyamfi (2015) Factors Affecting the Adoption of e-Marketing among SMEs: Case Study of Selected SMEs in the Kumasi Metropolis, Ashanti Region.

[15] Boateng, R., Molla, A., Heeks, R. and Hinson, R. (2011) Advancing E-Commerce beyond Readiness in a Developing Economy: Experiences of Ghanaian Firms. Journal of Electronic Commerce in Organizations, 9, 1-16.

https://doi.org/10.4018/jeco.2011010101

[16] Bajaj \& Leonard (2004) The CPT Framework: Understanding the Roles of Culture, 
Policy and Technology in Promoting Ecommerce Readiness.

[17] Fuseni, G. (2015) Small and Medium-Sized Enterprises' (Smes') Access to Credit in Ghana: Determinants and Challenges.

[18] Taylor and Owusu (2012) Factors Affecting Internet and e-Commerce Adoption among Small and Medium-Sized Enterprise Non-Traditional Exporters: Case Studies of Ghanaian Handicraft Exporters.

[19] Amoah, S.K. and Amoah, A.K. (2018) The Role of Small and Medium Enterprises (SMEs) to Employment in Ghana. International Journal of Business and Economics Research, 7, 151-157. https://doi.org/10.11648/j.ijber.20180705.14

[20] Mahmoud, M.A. (2011) Market Orientation and Business Performance among SMEs in Ghana.

[21] Kutner, et al. (2004) Applied Linear Statistical Models. 4th Edition, McGraw-Hill, New York. https://doi.org/10.5539/ibr.v4n1p241 